\title{
Challenges in tackling environmental concerns in indigenous education in Mexico
}

\author{
Rosa Guadalupe Mendoza-Zuany, Universidad Veracruzana, Mexico
}

\begin{abstract}
This article analyses the curriculum document called Indigenous language: Curriculum parameters, basic education, indigenous primary, that outlines study programmes for indigenous languages in Mexico, specifically for the Indigenous Language Subject in primary schools prescribed by the General Department of Indigenous Education (DGEI) of the Public Education Secretary (SEP) in 2008. The curriculum document will be analysed for its inclusion of topics and concerns pertaining to the environment, nature, biodiversity and indigenous territories. This analysis is relevant because the Indigenous Language Subject is the only curriculum area that has been designed by indigenous teachers, as part of their struggle to see their languages and cultures placed on a level with Spanish. Two important issues stand out from the analysis. Firstly, the curriculum document recognises community elders and parents as bearers and builders of indigenous knowledge concerning the environment. Second, it recognises that children learn from everyday cultural practices such as farming crops, local food production, etc. However, the analysis also revealed matters of concern, and these should be treated as challenges to be overcome.
\end{abstract}

Keywords: indigenous knowledge, indigenous education, environment, cultural practices, curriculum.

\section{Resumen}

En este artículo se analiza el documento "Lengua Indígena. Parámetros curriculares. Educación Básica. Primaria Indigena" - creado en 2008 - que propone programas de estudio para cada lengua indígena en México, específicamente para la Asignatura Lengua Indígena en escuelas primarias del subsistema indígena de la Dirección General de Educación Indígena (DGEI) de la Secretaría de Educación Pública (SEP) en México. Este documento curricular es analizado en torno a la inclusión de temas y preocupaciones sobre el medio ambiente, la naturaleza, la biodiversidad y los territorios indígenas. Este análisis es relevante, dado que la Asignatura Lengua Indígena ha constituido el único espacio curricular que han diseñado maestros indígenas en la lucha por el posicionamiento de sus lenguas y sus culturas a la par del español. Dos aspectos valiosos que sobresalen son el reconocimiento de los mayores y los padres de familia como portadores $y$ constructores de conocimiento indígena sobre la naturaleza, así como el aprendizaje de los niños a partir de prácticas culturales cotidianas como el cultivo, la producción local de alimentos, etc. Sin embargo, también derivan preocupaciones que debemos visualizar como retos educativos.

Palabras clave: conocimiento indígena, educación indígena, medio ambiente, prácticas culturales, currículum. 


\section{Introduction}

From a human rights perspective, basic education should be relevant for indigenous children in Mexico, both culturally and linguistically. There are 68 indigenous languages spoken in Mexico, with over 300 variants. Nevertheless, Agreement 592, which establishes the Implementation of Basic Education (2011) delineating the educational model in use up to 2017, and the proposed New Educational Model to be introduced gradually from 2018, both keep indigenous and culturally situational knowledge doubly on the margins of the national curriculum. It is only partially considered in the Indigenous Language Subject taught in indigenous pre-school and primary schools, which means that it is only taught to children who study within the indigenous sub-system schools, and not to indigenous or non-indigenous children who attend regular schools.

The indigenous knowledge in the subject includes the meanings attributed to nature and people's relationship to it, as well as meanings attributed to that which the indigenous peoples consider their territory; however, its coverage in the curriculum is restricted, marginal, insufficient and limited. The way the subject is constituted makes no recognition of the epistemological pluralism that is expressed in the distinctive ways indigenous people build knowledge in their own language, nor any recognition of indigenous peoples' ethical disposition towards their territory, which stands in contrast to the individual ownership and extractive model of modern neoliberalism. This problem is not exclusive to Mexico. With reference to South Africa, Shava and O’Donoghue (2014:4) note:'Our school curricula have, to a large extent, been highly westernised, with little opportunity for including indigenous knowledges. Indigenous knowledges have been excluded, marginalised, misrepresented, invalidated and labelled as inferior.'

Within this context, this article will analyse the curriculum document called Indigenous language: Curriculum parameters, basic education, indigenous primary (DGEI, 2008) that outlines study programmes for indigenous languages, specifically for the Indigenous Language Subject prescribed by the General Department of Indigenous Education (DGEI) of the Public Education Secretary (SEP) in 2008 and in force until 2017, when the New Educational Model was published, and which did not mention specific study programmes for languages. The curriculum document will be analysed for its inclusion of topics and concerns pertaining to the environment, nature, biodiversity and indigenous territories from plural systems of knowledge (western and indigenous).

It is relevant to look at the inclusion of the perspective of indigenous peoples regarding these issues, a perspective that I regard as indigenous knowledge (IK) and which Grenier (1998:1) defines as

unique, traditional, local knowledge existing within and developed around the specific conditions of women and men indigenous to a particular geographic area [...] [IK systems] are cumulative, representing generations of experiences, careful observations, and trial-and-error experiments.

This analysis is relevant because the Indigenous Language Subject is the only curriculum area designed by indigenous teachers, as part of their struggle to see their languages and cultures 
placed on a level with Spanish. One thing that stands out in this specific subject for providing education services to indigenous children is that the socio-environmental and territorial defence concerns of indigenous peoples have not been given sufficient, nor critical, space. The analysis will focus on some of the main features through which those who designed the curriculum document - indigenous education teachers and bureaucrats - tackled the environment, biodiversity and environmental problems.

Two important aspects that stand out are the recognition of community elders and parents as bearers and builders of indigenous knowledge concerning the environment, and the understanding that children learn from everyday cultural practices such as farming crops, local food production, etc. However, there are also concerns about the Indigenous Languages Subject that we should see as challenges, namely:

- The limited inclusion of topics concerning territory and the environment;

- The emphasis placed on the consequences rather than the causes of environmental problems;

- The limited range of textual products relating to these subjects;

- The lack of emphasis on the comparison of cultural perspectives; and

- The encyclopaedic nature of the texts to be produced by learners to preserve traditional knowledge in the indigenous discursive practices of daily life and in the curriculum.

\section{Panorama of the Mexican context}

To provide relevant education to the children and youth of indigenous peoples - as is their right - has been a complicated matter in Mexico as in the world at large. The way to understand key aspects of this matter as it manifests in Mexico is to examine the changing policies associated with the historically changing national project.

In the nineteenth and early twentieth centuries - periods of construction and reconstruction for the nation-state - cultural diversity was seen as an obstacle to national unity and the economic and social development of the country. In response, strongly homogenising cultural and linguistic processes were implemented. Schools took responsibility for hispanicising the population in a project that sought unity above everything else, failing to recognise the multicultural and linguistically diverse character of indigenous communities (Niembro Domínquez \& Mendoza-Zuany, 2017).

Since the 1990s, this homogenising strategy has changed and interculturality and bilingualism have instead become two fundamental elements in education for indigenous peoples. The rights of indigenous people in the area of education and in national and international law-making - demanded by indigenous movements that gained strength in the nineties - provide a frame of reference for improvements that should guide government action and educational policy (Mendoza-Zuany, 2017b).

The indigenous education sub-system in Mexico serves children and young people in indigenous nursery schools, pre-schools and primary schools in rural locations. Its objective is to provide, by means of an educational model within the framework of diversity, an equitable 
and educationally relevant focus that includes indigenous peoples' language and culture as necessary components of the curriculum. It is important to point out that indigenous education is based on the study plan and programmes followed by all Mexicans, both in the previous curriculum and in the New Educational Model. Its specificity arose through the offering of the Indigenous Language Subject in the curriculum framework. In 2011, the Basic Education Study Plan made the Indigenous Language Subject official in indigenous primary education, and it was added to the curriculum map aimed at indigenous education, making its teaching compulsory. In 2008, the DGEI stated, 'The Indigenous Language Subject should be complemented with the teaching of Spanish as a second language to thus cover the requirements of the Constitution to offer an inter-cultural and bilingual education' (DGEI, 2008:7). It was therefore necessary and unavoidable for the study programmes for these languages to be created so that indigenous children can have the opportunity to analyse, reflect on and study their mother tongue with the aim of widening its social use and using it consciously in their school learning and social life. The idea was for schools to contribute to indigenous learners' development of efficient oral and written communicative abilities in their indigenous languages and in Spanish as a second language.

Nevertheless, since 2008, important limitations have been observed regarding this subject. While there is a curriculum from which to develop study plans for this subject, programmes have only been designed for those languages that have a large number of speakers. In addition, text books for this subject have not been made available for learners. There is thus a serious lack of educational materials. An additional limitation is the fact that indigenous languages are only taught in pre-schools and primary schools. From secondary school onwards, education is provided exclusively in Spanish. The limited number of hours per week dedicated to this part of the curriculum is yet another failing.

It is also worth mentioning that indigenous children in Mexico do not only attend indigenous schools; some of them go to regular schools that do not teach the Indigenous Language Subject. This occurs mainly due to migration from the countryside to the city. The complexity of providing education for indigenous children is increased by difficulties in identifying them accurately. Learners can be considered indigenous by self-description and/ or because they speak an indigenous language. They may speak an indigenous language either as their mother tongue (L1) or as a second language (L2). Only 53.4\% of primary pupils who speak an indigenous language go to an indigenous school, which means that $46.6 \%$ of indigenous children in primary school are far from finding a path to the cultural and linguistic belonging that indigenous education aims to achieve (INEE-UNICEF, 2016). Furthermore, $73.2 \%$ of the indigenous population and nine out of ten school-aged speakers of indigenous languages live in poverty, which affects their access to, and continuity in, school (INEEUNICEF, 2016). Hence, the minimum requirements for social well-being are lacking, and this undoubtedly affects school performance.

The study programmes for each indigenous language have been promoted since 2008 against resistance, and their continuity is unsure under the recent New Educational Model, which makes no mention of specific study programmes in indigenous languages. In 2017, a New Educational Model and a Curriculum Proposal for Compulsory Education were proposed 
(covering pre-school to high school). Although a specific space for indigenous education is still considered within the subject 'Mother tongue' (this includes 'Indigenous tongue' and 'Second language'), the subject area 'Language and communication' makes a single proposal for all indigenous languages, disregarding the fact that each indigenous group has their own distinct culture, language and way of seeing and recreating life. Therefore, the learning of language and culture according to each group's frames of reference is not tackled in specific programmes for each language.

With the New Model, we still have limited curriculum space, since the eight hours set aside for Mother-tongue will be divided up to give five hours to Mother-tongue and three hours to Second language (the classification of Mother-tongue versus Second language varies from school to school depending on a socio-linguistic diagnostic that specifies the language for an area).

One important and positive innovation in the New Educational Model is that the Indigenous Language Subject can be taught as L1 or L2, depending on each school's sociolinguistic diagnostic. These changes in the model are part of a tendency in educational policy for indigenous peoples that has moved from an intercultural focus to an inclusive one. This has important implications (Mendoza-Zuany, 2017a), among which we can identify the tendency towards the construction of an educational system without an indigenous sub-system, under the premise that indigenous peoples are vulnerable groups who should be served in the same, inclusive school with a single classroom for all.

In this article, our analysis will focus on the curriculum document which, from 2008 to 2017, allowed for the design of study programmes for each language. It was under the coordination of the Department for the Strengthening and Development of Indigenous Languages (Dirección de Fortalecimiento y Desarrollo de las Lenguas Indígenas) of the DGEI that, since 2008, study programmes and teacher books have been created for some indigenous languages, containing instructional projects to specifically tackle the languages' social practices and the instructional orientation for their implementation. As has been mentioned, the designing committees that created the study programmes were made up of teachers who speak the languages in question. These committees receive continuous training and support to carry out this curriculum work. The teachers, principals, supervisors and technical assessors who work with the languages that have study programmes periodically receive training and support for the teaching of Spanish as a second language and have access to educational projects that allow them to foster the development of bilingualism among indigenous children.

Those teachers who work with languages that have no study programmes, however, create their own instructional strategies based on the general document, Indigenous language: Curriculum parameters, basic education, indigenous primary (DGEI, 2008). This document will be analysed here.

It is important to stress that the significance of analysing the curriculum document supporting the Indigenous Language Subject lies in the fact that this document lays the foundations for the curriculum design. This is now the only space available for the inclusion of indigenous knowledge in a homogenising national curriculum, one that - through exclusion and sometimes through folklorisation - does not recognise the epistemic plurality of indigenous knowledge. 


\section{Indigenous peoples and their territories}

Educational policy cannot ignore the ancient relationship between indigenous peoples and their ecological surroundings and the knowledge built from extracting their territories' resources as a means of survival. In terms of cultural and biological diversity alone, Toledo and Barrera-Bassols demonstrate the connections between linguistic, biological, genetic, cognitive, agricultural and scenic diversity that make up a 'biological-cultural' complex (2009:25) that is the result of thousands of years of interaction between traditional societies and their ecosystems. International treaties also recognise the close links between indigenous populations and their biological environment. For example, the Convention on Biological Diversity, ratified by Mexico, mentions the agreement to 'respect, preserve and maintain knowledge, innovations and practices of indigenous and local communities embodying traditional lifestyles relevant for the conservation and sustainable use of biological diversity' (Article 8(j)).

Toledo and Barrera-Bassols (2009) calculate the indigenous population of the world at over 330 million people living in 75 of the world's 184 nations, including groups in each of the planet's main ecosystems, especially those terrestrial and aquatic ecosystems least touched by humankind (Burger, 1987). An example of the overlap between indigenous peoples and highly biodiverse areas is that which occurs in tropical rainforests: 'there is a clear correspondence between areas of remaining tropical forests and the presence of indigenous peoples in Latin America, the Congo Basin in Africa, and several countries of tropical Asia' (Toledo \& BarreraBassols, 2009:53).

The richness of landscapes and knowledge that have been generated in these overlaps between biological and cultural diversity is not restricted to the way in which ecosystems in indigenous territories have been preserved. It also covers the processes of domestication and production of new ecologically and commercially important species that have been developed through centuries of experimentation and detailed observation of the ecological processes in the environments where they have historically occurred. Most of the crops that feed the world have passed through domestication processes carried out by indigenous peoples. These species, products and sub-products have evolved through a long process of selection, diversification, innovation, exchange with other regions, adaptation and genetic improvement (Boege, 2008) over many generations. This reveals that there is not only cultural or biological richness, but also a richness of practices and knowledge that have been developed to meet the basic needs of human populations.

Despite the fact that most of the world's biological wealth is under the guardianship of indigenous peoples, the advent of modernity has subjected these peoples to a range of pressures that compromise the socio-ecological processes they depend on. Mining is one example. The insufficiently regulated extraction of minerals from indigenous territories provokes severe environmental damage (Alimonda, 2011). The effects of climate change on indigenous peoples is another important pressure to consider in how it relates to educational policies for indigenous communities (Salick \& Byg, 2007). These negative effects include decreasing access to water and changes in the traditional cycles of planting and harvesting - both of which compromise indigenous peoples' capacity to produce food for survival. 


\section{Nature, environment and territory in indigenous languages' study programmes}

The curriculum document - Indigenous language curriculum parameters: Basic education, indigenous primary - was written by 30 bilingual indigenous teachers of various languages, with input from expert academics. It arose from 'the idea that the study of language at school should promote reflection concerning the language itself and its uses, including the language of school life' (DGEI, 2008:11). It proposes that study programmes should be rooted in language practices that are related to the following four areas, with specific content recommended for each area:

1. Family and community life;

2. Oral tradition, literature and historical testimony;

3. Inter-community life and relationships with other peoples; and

4. The study and dissemination of knowledge. (DGEI, 2008:16)

The programmes are arranged in cycles: a first cycle covering first and second grade in primary school (6-8 years old); a second cycle that covers third and fourth grade (9-10 years old); and a third cycle covering children aged 11 to 12 .

The two valuable aspects of the curriculum document discussed next relate to living people as bearers of knowledge transmitted through everyday cultural practices.

\section{Older people and parents as transmitters of knowledge}

The curriculum document refers to the elders, the knowers and parents as bearers of knowledge, and as validators of this information that children are encouraged to write down. Similarly, the knowledge children gain within the family is emphasised, for example through the teachings of their parents regarding agricultural activities and other means of production, such as tending cattle, fishing, weaving, etc. A specific example could be that of a recipe book composed with the collaboration of the children's mothers and their knowledge of traditional units of measurement.

The inclusion of older people and parents as transmitters of knowledge helps to counter the fact that school curricula have 'excluded the role of parents and elderly people in the education of their children about their culture, values and livelihoods' (Shava \& O'Donoghue, 2014:4). According to Grenier (1998:5):

more and more knowledge is being lost as a result of the disruption of traditional channels of oral communication [...] because IK is transmitted orally, it is vulnerable to rapid change - especially when people are displaced or when young people acquire values and lifestyles different from those of their ancestors.

\section{Knowledge from personal experience}

Indigenous knowledge comes from participating in group work in families and communities, and is created through the children's own experiences. The document suggests projects that will encourage children to reflect on their knowledge-producing experiences: 
The knowledge of local production is not restricted to specific information, but considers experiences, the use of instruments, values, ways of relating to nature, the practice of rituals or ceremonies, discourses, and many other aspects. Reflecting on these experiences, and their participation in agricultural work or other trades passed on by their parents (handicrafts, for example) helps them understand their participation in group work, and the importance of these practices for their family and community life. (DGEI, 2008:132)

This approach counters the exclusion that Shava and O'Donoghue have also observed in the South African context: 'Education institutions (such as schools) in particular have been zones of exclusion of such knowledge. This has created a situation where what the learners learn at school is different form their lived experiences at home' (2014:4).

\section{Concerns and challenges}

Having pointed out two positive aspects, the analysis of the curriculum document also reveals certain challenges.

\section{Insufficiency of topics relating to territory and the environment}

The insufficient incorporation of topics relating to territory and environment (such as care for the environment, plants, etc.) becomes apparent when it is observed that practically the only area in which these issues arise is that associated with 'Study and diffusion of knowledge'. The ritual language of ceremonies commemorating mother nature is marginally tackled in the area 'Family and community life'. Projects relating to nature are not mentioned at all in the subject area 'Oral tradition, literature and historical testimony', nor in 'Inter-community life and relationships with other peoples', except for sporadic instructions to record oral and written narrations of real events 'concerning natural phenomena' and experiences of nature. For example, out of 24 projects suggested for the first cycle, only three refer to any topic related to the environment; in the second cycle, only six out of 34 projects refer to such topics; and, in the third cycle, only three out of 35 projects make any such references (DGEI, 2008).

The potential that the traditional management of territory and landscape clearly presents is not taken advantage of as a context for generating learning and critical reflection on the problems and challenges directly affecting indigenous communities (Brandt, 2013).

\section{Emphasis on the consequences of environmental problems, not their causes}

We notice an emphasis on the consequences rather than the causes of environmental problems; community, inter-community and extra-community tensions caused by the management of their territories and natural resources are also left out of the picture. For instance, in suggesting that students record and narrate current events 'relating to natural phenomena', emphasis is placed on recording a 'testimony of consequences or effects on community life' (DGEI, 2008:38). Whilst we point out the obvious limitation of referring to natural phenomena as the only current events to be recorded, it is also worth noting that there is no instruction to 
investigate the causes of current events and socio-environmental problems (e.g. climate change, fracking, open-cast mining).

In 'Study and the dissemination of knowledge' in the second cycle, there is a suggested project to investigate measures for preventing the consumption of foods containing toxic substances; nevertheless, the socio-environmental aspect of the problem is not addressed and there is no suggestion to investigate why herbicides are used, which interested parties promote their use, and what the relationship is between their use and the (unhealthy) condition of water sources. In the same vein, in the proposed project to organise a campaign to popularise environmental protection behaviours in order to prevent pollution (of the water, earth or air), it is only suggested that pupils investigate conservation activities, without any emphasis on investigating the community and extra-community consumption and the damaging behaviours (material practices) that cause these different types of pollution. Activities are promoted that respond to external interests and concerns rather than to local concerns about the environment.

Further, there is no promotion of research projects that could involve children as active researchers (Barrat Hacking et al., 2013) of their own realities, or that could help them to develop a critical view of the issues affecting them and how these issues could be resolved.

Finally, there is no recognition that bearers of traditional knowledge systems look at problems holistically, with all their complexities and multiple connections (Grenier, 1998).

\section{Lack of variety of texts relating to territory and the environment}

In these proposed projects, there is little variety in the materials relating to environmental topics - these being limited to lists of plants and their properties, catalogues, lists of herbal medicines and posters. In the first cycle, for instance, a project is proposed to draw up lists of crops and plants; in the second cycle, to produce catalogues and lists of herbal medicines; and in the third cycle, catalogues are again suggested along with descriptions of medicinal plants and their uses. Only one project suggests the production of a book of questions and answers, recommendations and advice concerning crops.

The lack of analytical texts that could introduce reflection and analysis is a significant gap in the subject. While the subject is fundamentally directed towards language teaching, it could still incorporate experiential learning and learning-by-doing experiences (Shava \& O'Donoghue, 2014) that would lead to active participation in events and to demonstrations of cultural practices in or outside the classroom, amongst other activities. The emphasis on specific textual products directed towards developing linguistic ability ignores the potential for developing such analytical skills as suggested by Shava and O'Donoghue (2014:33):

appreciating the enormous variety of life and life systems in the local (and global) context(s) [...] the conceptualisation of how different living organisms are interrelated in nature and the natural processes within ecosystems; [...] understanding the impacts of human activities on ecosystems, their interrelated nature and the implications to human well-being; and appreciating the role of indigenous science in the development of the range of responses to ecosystem loss. 


\section{Little emphasis on the comparison of cultural perspectives}

Although the production of texts with a cultural perspective regarding environmental care is alluded to, there is no actual suggestion to contrast this perspective - or enter into dialogue with different perspectives covered in other subjects in the national curriculum that relate to the environment.

One important source of contrasting perspectives is covered in the subjects 'Knowledge about the environment' (first and second grade), 'Natural sciences and technology' and 'Geography' (third to sixth grade), and 'Stories, landscape and coexistence in my area' (third grade). Reference is made, for example, to the interpretation of natural phenomena to forecast the weather, but without insisting on the importance of such examples in demonstrating the production of valid knowledge that is not tied to the hegemonic scientific method. This is not just about recording alternative meanings for natural phenomena, but rather about creating a dialogue between these meanings and the hegemonic meanings, and about valuing present-day indigenous ways of creating knowledge that could be used as strategies directed towards the development of critical thinking among indigenous learners, as exemplified in Maurial's proposal, Indigenous Dialogical Education (1999). The underlying idea in the curriculum document and the educational practices is that interpretation from their own cultural perspective is traditional, and the traditional is not current, which becomes apparent when students talk about natural phenomena and their consequences, comparing their traditional worldview with a present-day perspective (DGEI, 2008:135).

\section{Encyclopaedic nature of the texts for preserving traditional knowledge}

We can also point out the 'encyclopaedic nature' of the texts to be produced, for example, when suggesting a record of plants 'facing extinction' (DGEI, 2008:90) in a list of herbal medicines. The rationale is that this knowledge is being lost (DGEI, 2008:50) and therefore we need to record, organise, promote and preserve it. To justify this, the value of writing as a way of preserving knowledge is invoked. This is important, but this approach might produce a static version of the collected knowledge, without considering current and dynamic cultural practices.

In each cycle, older traditions are introduced into projects in 'Oral tradition, literature and historical testimony', for example promoting the recording of traditional stories that include references to animals, plants, sacred places, and the origin of the world and the human race. No advantage is taken of the fact that the community can also be a classroom (Semali, 1999) in which students can connect the proposals of the curriculum with the knowledge of the community. The 'encyclopaedic' knowledge becomes disconnected from practices occurring in the framework of a belief system which has been transmitted from generation to generation (George, 1999). Thus

the main hurdle to be overcome is the fact that indigenous knowledge is not normally 'packaged' as school materials are. The school teacher must, therefore, first access the indigenous knowledge, then understand it and its likely relation to what is to be taught in the class. Furthermore, s(he) must devise teaching strategies for using it effectively. (George, 1999:84) 


\section{Conclusions}

The fact that the Indigenous Language Subject is intended to develop linguistic abilities does not preclude the possibility of its deliberately strengthening some aspects of environmental education related to indigenous contexts.

Finding ourselves in a chrono-pedagogical stage in which we understand the environmental crisis, we recognise the human and ecological factors that cause it. The challenge of the transformation necessary to build an environmentally sustainable and socially fair society makes education a political - not just pedagogical - act that directs us towards values and attitudes for such a transformation (Caride \& Meira, 2001). In particular, education for indigenous peoples, through the only specific curriculum space - the Indigenous Language Subject - should be taken up as a political act that promotes analysis and reflection concerning the environment and indigenous peoples' territories in a global context. The subject should be seen as a curriculum space that goes beyond the development of linguistic ability to develop analytical skills as well. As such, it requires a greater variety of learning products.

This subject should also give the child a sense of their place in the world - both globally and locally - and favour the recognition of cultural diversity as well as the capacity of each indigenous group for building specific sustainable projects in dialogue with others. Doing so will require going beyond the encyclopaedic approach of tackling the environment and biodiversity in order to place these issues in a specific place and time, recognising their dynamism and changeability.

\section{About the contributor}

\section{Mendoza-Zuany, Rosa Guadalupe | Universidad Veracruzana, Mexico ORCID 0000-0002-5503-4158 | lupitamendoza.zuany@gmail.com}

Rosa gained her $\mathrm{PhD}$ in Politics from the University of York (United Kingdom). Her research interests are educational policies in culturally diverse contexts and a critical revision of inclusion as a replacement for interculturality.

\section{References}

Alimonda, H. (Coord.) (2011). La naturaleza colonizada: Ecología política y minería en América Latina. Buenos Aires: Ediciones CICCUS.

Barrat Hacking, E. et al. (2013). Children as active researchers: The potential of environmental education research involving children. In R. B. Stevenson et al. (Eds), International handbook of research on environmental education (pp. 438-458). New York and London: Routledge, AERA.

Boege, E. (2008). El patrimonio biocultural de los pueblos indígenas de México. Hacia la conservación in situ de la biodiversidad y agrodiversidad en los territorios indígenas. México, D.F.: Instituto Nacional de Antropología e Historia, Comisión Nacional para el Desarrollo de los Pueblos Indígenas. 
Brandt, C.B. (2013). Landscapes as contexts for learning. In R. B. Stevenson et al. (Eds), International handbook of research on environmental education (pp. 275-288). New York and London: Routledge, AERA..

Burger, J. (1987). Report from the frontier: The state of the world's indigenous peoples. London: Zed Books.

Caride, J.A. \& Meira, P.A. (2001). Educación ambiental y desarrollo humano. Barcelona: Editorial Ariel.

DGEI (2008). Lengua Indígena. Parámetros Curriculares. Educación Básica. Primaria Indígena. México: CONALITEG.

George, J.M. (1999). Indigenous knowledge as a component of the school curriculum. In L.M. Semali \& J.L. Kincheloe (Eds), What is indigenous knowledge? Voices from the academy (pp. 79-94). New York and London: Falmer Press.

Grenier, L. (1998) Working with indigenous knowledge. A guide for researchers. Ottawa: International Development Research Centre.

INEE-UNICEF (2016). Panorama educativo de la población indígena 2015. México: INEE.

Maurial, M. (1999). Indigenous knowledge and schooling: A continuum between conflict and dialogue. In L.M. Semali \& J.L. Kincheloe (Eds), What is indigenous knowledge? Voices from the academy (pp. 59-78). New York and London: Falmer Press.

Mendoza-Zuany, R.G. (2017a). Inclusión educativa por interculturalidad: implicaciones para la educación de la niñez indígena. Perfiles Educativos, 158, 52-69.

Mendoza-Zuany, R.G. (2017b). Evaluación de la Política Educativa Dirigida a la Población Indígena en Educación Básica. México: INEE.

Niembro Domínguez, M.C. \& Mendoza-Zuany, R.G. (2017). La educación indígena en Veracruz: diagnóstico y recomendaciones para la política educativa. Xalapa: Biblioteca Digital de Investigación Educativa, Universidad Veracruzana.

Salick, J. \& Byg, A. (2007). Indigenous peoples and climate change. Oxford: Tyndall Centre for Climate Change Research.

Semali, L.M. (1999). Community as classroom: (Re)Valuing indigenous literacy. In L.M. Semali \& J.L. Kincheloe (Eds), What is indigenous knowledge? Voices from the academy (pp. 95-118). New York and London: Falmer Press..

SEP (2017). Aprendizajes clave para la educación integral. Plan y programas de estudio para la educación básica. México: SEP.

Shava, S. \& O’Donoghue, R. (2014). Teaching indigenous knowledge and technology. Grahamstown: Fundisa for Change Programme, Environmental Learning Research Centre, Rhodes University, South Africa.

Toledo, V.M. \& Barrera-Bassols, N. (2009). La memoria biocultural la importancia ecológica de las sabidurías tradicionales. Barcelona: Icaria Editorial. 